\title{
Compendium of Current Total Ionizing Dose Results and Displacement Damage Results for Candidate Spacecraft Electronics for NASA
}

\author{
Donna J. Cochran, Stephen P. Buchner, Christian Poivey, Kenneth A. LaBel, Ray L. Ladbury, Martha \\ O'Bryan, James W. Howard, Jr., Anthony Sanders, and Timothy Oldham
}

\begin{abstract}
Sensitivity of a variety of candidate spacecraft electronics to total ionizing dose and displacement damage is studied. $\square$ Devices tested include optoelectronics, digital, analog, linear bipolar devices, and hybrid devices.
\end{abstract}

Index Terms- Displacement Damage, optoelectronics, Proton Damage, Total Ionizing Dose, and Single Event Effects.

\section{INTRODUCTION}

In order to meet the cost, performance, and schedule demands imposed by the space flight community, commercial and emerging technology devices have assumed a prominent role in meeting these needs. Thus, the importance of ground based testing for the effects of total ionizing dose (TID) and proton displacement damage to qualify such devices for flight is paramount. The novel ways in which some of these devices are used also highlights the need for application

This work was supported in part by the NASA Electronic Parts and Packaging Program (NEPP), NASA Flight Projects, and the Defense Threat Reduction Agency (DTRA).

Donna J. Cochran, MEI Technologies Inc., c/o NASA Goddard Space Flight Center (GSFC), Code 561.4, Bldg. 22, Rm. 062A, Greenbelt, MD 20771 (USA), phone: 301-286-8258, fax: 301-286-4699, email: dcochran@pop700.gsfc.nasa.gov

Martha V. O'Bryan, MEI Technologies Inc., c/o NASA Goddard Space Flight Center (GSFC), Code 561.4, Bldg. 22, Rm. 062A, Greenbelt, MD 20771 (USA), phone: 301-286-1412, fax: 301-286-4699, email: martha.obryan@gsfc.nasa.gov

Stephen P. Buchner, Perot Systems., c/o NASA/GSFC, Code 561.4, Greenbelt, MD 20771 (USA), phone: 301-286-5019, email: sbuchner@pop500.gsfc.nasa.gov

Christian Poivey, MEI Technologies, Inc., c/o NASA/GSFC, Code 561.4, Greenbelt, MD 20771 (USA), phone: 301-286-2128, email: cpoivey@pop500.gsfc.nasa.gov

Ray L. Ladbury, NASA/GSFC, Code 561.4, Greenbelt, MD 20771 (USA), (USA), phone: 301-286-1030, email: rladbury@pop500.gsfc.nasa.gov

Kenneth A. LaBel, NASA/GSFC, Code 561.4, Greenbelt, MD 20771 (USA), phone: 301-286-9936, email: Kenneth.A.Label@nasa.gov specific testing to ensure their proper operation and ability to meet mission goals.

The test results presented here were gathered to establish the sensitivity of the devices selected as candidate spacecraft electronics to TID and proton damage. Proton-induced degradation is a mix of ionizing (TID) and non-ionizing damage. This non-ionizing damage is commonly referred to as displacement damage (DD). This testing serves to determine the limit to which a candidate device may be used in space applications. For single event effects (SEE) results, see a companion paper submitted to the 2007 IEEE NSREC Radiation Effects Data Workshop entitled: "Compendium of Current Single Event Effects Results for Candidate Spacecraft Electronics for NASA " by M. O'Bryan, et al. [1]

\section{TEST TECHNIQUES AND SETUP}

\section{A. Test Facilities - TID}

$B$. TID testing was performed using a Co- 60 source at the Goddard Space Flight Center Radiation Effects Facility (GSFC REF), Table I. The source is capable of delivering a dose rate in excess of $30 \mathrm{rads}(\mathrm{Si}) / \mathrm{s}$, with dosimetry being performed using a chamber probe.

\section{Test Facilities - Proton}

Proton DD/TID tests were performed at two facilities: The University of California at Davis (UCD) Crocker Nuclear Laboratory (CNL) that has a 76" cyclotron (maximum energy of $63 \mathrm{MeV}$ ), and the Indiana University Cyclotron Facility (IUCF) that has an 88" cyclotron (maximum energy of 205 $\mathrm{MeV}$ ). Table II lists the proton damage test facilities and energies used on the devices. 
Table I: Proton Test Facilities

\begin{tabular}{|l|c|}
\hline \multicolumn{1}{|c|}{ Facility } & $\begin{array}{c}\text { Proton Energy, } \\
\text { (MeV) }\end{array}$ \\
\hline $\begin{array}{l}\text { University of California at Davis } \\
\text { Crocker Nuclear Laboratory (UCD-CNL) }\end{array}$ & $26.6-63$ \\
\hline $\begin{array}{l}\text { Indiana University Cyclotron Facility } \\
\text { (IUCF) }\end{array}$ & \\
\hline
\end{tabular}

\section{Test Methods}

Unless otherwise noted, all tests were performed at room temperature and with nominal power supply voltages.

\section{1) TID Testing}

TID testing was performed to the MIL-STD-883 1019.7 test method [2].

\section{2) Proton Damage Testing}

Proton damage tests were performed on biased devices with functionality and parametrics being measured either continually during irradiation (in-situ) or after step irradiations (for example: every $10 \mathrm{krads}(\mathrm{Si})$, or every $1 \times 10^{10}$ protons).

\section{TEST RESUlTS OVERVIEW}

Abbreviations for principal investigators (PIs) are listed in Table II.. Abbreviations and conventions are listed in Table III. Table IV provides a summary of TID and DD test results. This paper is a summary of results. Please note that these test results can depend on operational conditions. Complete test reports are available online at http://radhome.gsfc.nasa.gov [3].

TABLE II: LIST OF PRINCIPAL INVESTIGATORS

\begin{tabular}{|c|c|}
\hline Abbreviation & Principal Investigator (PI) \\
\hline SB & Steve Buchner \\
\hline JH & Jim Howard \\
\hline TO & Timothy Oldham \\
\hline CP & Christian Poivey \\
\hline AS & Anthony Sanders \\
\hline
\end{tabular}

TABLE III: ABBREVIATIONS AND CONVENTIONS:

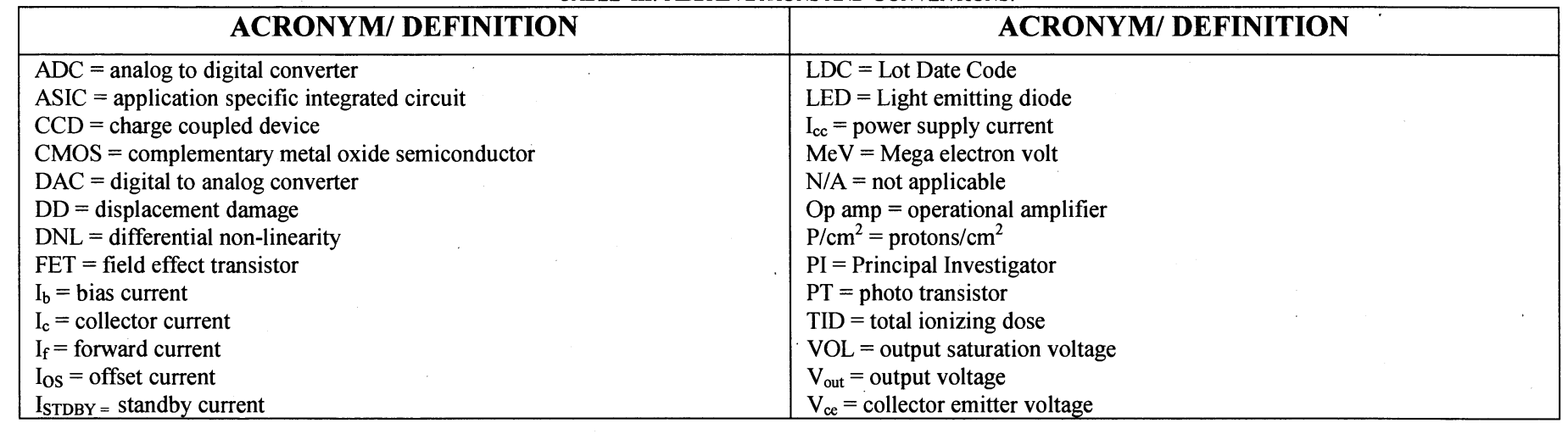


TABLE IV: SUMMARY OF TID AND DD TEST RESULTS

\begin{tabular}{|c|c|c|c|c|c|c|c|c|}
\hline Part Number & Manufacturer & LDC & Function & \begin{tabular}{|c|} 
Facility Date/P.I \\
(Co-60 source unless \\
otherwise noted $)$
\end{tabular} & Summary of Results [Test Report] & $\begin{array}{l}\text { Dose rate } \\
(\operatorname{rads}(\mathbf{S i}) / \mathbf{s})\end{array}$ & $\begin{array}{c}\text { Degradation } \\
\text { Level } \\
(\text { krads(Si)) }\end{array}$ & $\begin{array}{l}\text { Appl } \\
\text { Spec }\end{array}$ \\
\hline \multicolumn{9}{|l|}{ Data Converters } \\
\hline AD565 & Analog Devices & $0013 \mathrm{~F}$ & 12-bit DAC & GSFC06ЛU/SB & $\begin{array}{l}\text { All parts passed functional testing up to } 100 \mathrm{krad}(\mathrm{Si}) \text { at low } \\
\text { dose rate. All parametric values were within specifications up } \\
\text { to } 40 \mathrm{krad}(\mathrm{Si}) \text {. One part failed differential nonlinearity at } 50 \\
\operatorname{krad}(\mathrm{Si}) \text { and } 6 \text { parts failed at } 75 \mathrm{krad}(\mathrm{Si}) \text {. }\end{array}$ & 0.02 & 50 to 75 & $\mathrm{~N}$ \\
\hline AD670 & Analog Devices & $044 \mathrm{~A}$ & 8-bit ADC & GSFC06OCT/SB & $\begin{array}{l}\text { One part failed functionally between } 5 \text { and } 10 \mathrm{krad}(\mathrm{Si}) \text {. Two } \\
\text { parts failed functionally between } 10 \text { and } 15 \mathrm{krad}(\mathrm{Si}) \text { and one } \\
\text { part failed functionally between } 15 \mathrm{krad}(\mathrm{Si}) \text { and } 20 \mathrm{krad}(\mathrm{Si}) \text {. }\end{array}$ & 0.02 & 5 to 20 & $\mathrm{~N}$ \\
\hline LTC1419 & Linear Tech & 0118 & $\mathrm{ADC}$ & GSFC06OCT/SB & $\begin{array}{l}\text { Some parametric values for some parts were out of } \\
\text { specification before exposure to ionizing radiation. Some of } \\
\text { the results lacked consistency as evidenced by the fact that } \\
\text { their values were out of specification at low doses and within } \\
\text { specification at higher doses. These results should be carefully } \\
\text { vetted before deciding to use them. }\end{array}$ & 2 & $\begin{array}{l}\text { inconclu- } \\
\text { sive }\end{array}$ & $\mathrm{N}$ \\
\hline \multicolumn{9}{|l|}{ Discretes } \\
\hline $\begin{array}{l}\text { IMEC } 65 \mathrm{~nm} \text { test } \\
\text { Transistors }\end{array}$ & IMEC & $\begin{array}{c}\mathrm{n} / \mathrm{a} \\
\text { test samples }\end{array}$ & $\begin{array}{l}65 \mathrm{~nm} \text { test } \\
\text { structures, } \mathrm{N} \text { and } \mathrm{P} \\
\text { MOSFETS }\end{array}$ & GSFC06NOV/CP & No degradation up to $150 \mathrm{krad}(\mathrm{Si})$. & $\begin{array}{l}\text { LDR: } 0.1 \\
\text { HDR: } 4\end{array}$ & $>150$ & $\mathrm{~N}$ \\
\hline JANS2N2222 & Analog Devices & 0315 & Transistors & GSFC06OCT/SB & $\begin{array}{l}\text { The four parts tested passed Vce (saturation voltage) and Vbe } \\
\text { up to a total dose of } 40 \mathrm{krad}(\mathrm{Si}) \text {. The forward current transfer } \\
\text { ration went out of specification for two devices between } 30 \\
\text { and } 40 \mathrm{krad}(\mathrm{Si}) \text {. }\end{array}$ & 0.02 & 30 to 40 & $\mathrm{~N}$ \\
\hline JANS2N3501 & Analog Devices & 0002 & Transistors & GSFC06AUG/SB & $\begin{array}{l}\text { The four parts tested passed all parametric and functional tests } \\
\text { up to a total dose of } 40 \mathrm{krad}(\mathrm{Si}) \text {. }\end{array}$ & 0.02 & $>40$ & $\mathrm{~N}$ \\
\hline \multicolumn{9}{|c|}{ Linear - Amplifiers } \\
\hline OP200 & Analog Devices & 0237A & Op Amp & GSFC06AUG/SB & $\begin{array}{l}\text { The input bias current went out of specification for all three } \\
\text { parts between } 20 \text { and } 30 \mathrm{krad}(\mathrm{Si}) \text {. }\end{array}$ & 0.02 & 21 to 40 & $\mathrm{~N}$ \\
\hline OP400 & Analog Devices & 0349F & Op Amp & GSFC06AUG/SB & $\begin{array}{l}\text { The supply current and input offset voltage } \\
\text { remained within specifications up to } 50 \mathrm{krad}(\mathrm{Si}) \text {. } \\
\text { The input bias current went out of specification } \\
\text { between } 6 \text { and } 11 \mathrm{krad}(\mathrm{Si}) \text {. }\end{array}$ & 0.02 & 6 to 11 & $\mathrm{~N}$ \\
\hline AD524 & $\begin{array}{c}\text { National } \\
\text { Semiconductor }\end{array}$ & $\begin{array}{l}0502 \mathrm{~A} \text { and } \\
0606\end{array}$ & Instrument Op Amp & GSFC06NOV/SB & $\begin{array}{l}\text { The input bias current went out of specification at a total dose } \\
\text { of less than } 5 \mathrm{krad}(\mathrm{Si}) \text {. The input offset voltage went out of } \\
\text { specification at } 40 \mathrm{krad}(\mathrm{Si}) \text {. One device failed the specification } \\
\text { for output offset voltage between } 5 \text { and } 10 \mathrm{krad}(\mathrm{Si}) \text {. }\end{array}$ & 0.02 & 5 to 10 & $\mathrm{~N}$ \\
\hline OP27A & Analog Devices & 0448 & Op Amp & GSFC06JAN/SB & $\begin{array}{l}\text { Input bias current and input offset current go out of } \\
\text { specification between } 20 \text { and } 30 \mathrm{krad}(\mathrm{Si}) \text {. }\end{array}$ & 0.02 & 20 to 30 & $\mathrm{~N}$ \\
\hline OP11 & Analog Devices & $0412 \mathrm{~F}$ & Op Amp & GSFC05DEC/SB & $\begin{array}{l}\text { Testing was done for a specific application that was different } \\
\text { from used to generate the data in the data sheet. Therefore no } \\
\text { comparison with the specifications could be made. }\end{array}$ & 0.02 & $18-20$ & $\mathrm{Y}$ \\
\hline OP42 & Analog Devices & $0223 \mathrm{~A}$ & Op Amp & GSFCTBD/SB & $\begin{array}{l}\text { Supply current and input bias current exceeded parametric } \\
\text { values between } 5 \text { and } 10 \mathrm{krad}(\mathrm{Si}) \text {. Input offset voltage went }\end{array}$ & 0.02 & $5-10$ & $\mathrm{~N}$ \\
\hline
\end{tabular}




\begin{tabular}{|c|c|c|c|c|c|c|c|c|}
\hline Part Number & Manufacturer & LDC & Function & $\begin{array}{c}\text { Facility Date/P.I } \\
\text { (Co-60 source unless } \\
\text { otherwise noted })\end{array}$ & Summary of Results [Test Report] & $\begin{array}{l}\text { Dose rate } \\
(\operatorname{rads}(\mathbf{S i}) / \mathbf{s})\end{array}$ & $\begin{array}{c}\text { Degradation } \\
\text { Level } \\
(\operatorname{krads}(\mathbf{S i})) \\
\end{array}$ & $\begin{array}{l}\text { Appl } \\
\text { Spec }\end{array}$ \\
\hline & & & & & out of specification between 0 and $5 \mathrm{krad}(\mathrm{Si})$. & & & \\
\hline LT1037 & Linear Tech & $9846 \mathrm{~B}$ & Op Amp & GSFC06APR/CP & $\begin{array}{l}\text { All parts passed } 7 \mathrm{krad}(\mathrm{Si}), \mathrm{Ib} \text { is out of specification } \\
\text { limits for all parts at } 15 \mathrm{krad}(\mathrm{Si}) \text {. }\end{array}$ & $<1$ & 7 & $\mathrm{~N}$ \\
\hline \multicolumn{9}{|l|}{ Logic Devices } \\
\hline 54ACTQ14 & $\begin{array}{c}\text { National } \\
\text { Semiconductor }\end{array}$ & 0545A & $\begin{array}{l}\text { HEX Inverter with } \\
\text { Schmitt Trigger }\end{array}$ & GSFC06JUL/SB & $\begin{array}{l}\text { All the parametric values were within specifications } \square \text { up to a } \\
\text { total ionizing doese of } 100 \mathrm{krad}(\mathrm{Si}) \text {. }\end{array}$ & 2 & $>100$ & $\mathrm{~N}$ \\
\hline 54ACTQ244 & $\begin{array}{c}\text { National } \\
\text { Semiconductor }\end{array}$ & 0548B & $\begin{array}{l}\text { Quiet Series Octal } \\
\text { Buffer/Line Driver }\end{array}$ & GSFC06AUG/SB & $\begin{array}{l}\text { All parametric values were within specifications after being } \\
\text { exposed to } 50 \mathrm{krad}(\mathrm{Si}) \text { followed by a one week anneal except } \\
\text { for the supply current which exceeds specifications after } 20 \\
\text { krad(Si) and Tristate Output Leakage Current which exceeds } \\
\text { specifications after a total dose of } 50 \mathrm{krad}(\mathrm{Si}) \text {. }\end{array}$ & 2 & 20 to 50 & $\mathrm{~N}$ \\
\hline 54ACTQ16244 & $\begin{array}{c}\text { National } \\
\text { Semiconductor }\end{array}$ & $\begin{array}{l}0435 \text { and } \\
0548\end{array}$ & $\begin{array}{l}\text { 16-bit Buffer/Line } \\
\text { Driver }\end{array}$ & GSFC06AUG/SB; & All parts passed all functional tests up to a TID of $50 \mathrm{krad}(\mathrm{Si})$ & 2 & $>50$ & $\mathrm{~N}$ \\
\hline \multicolumn{9}{|l|}{ Linear Other } \\
\hline SG1526 & Micro-Semi & & $\begin{array}{l}\text { Pulse Width } \\
\text { Modulator }\end{array}$ & GSFC06AUG/SB & $\begin{array}{l}\text { The input bias current went out of specification between } 10 \\
\text { and } 20 \mathrm{krad}(\mathrm{Si}) \text {. No other parameters changed with TID up to } \\
40 \mathrm{krad}(\mathrm{Si}) \text {. }\end{array}$ & 0.02 & $10-20$ & $\mathrm{~N}$ \\
\hline UC1708 & Texas Instruments & 0224B & $\begin{array}{l}\text { Non-inverting high } \\
\text { speed power driver }\end{array}$ & GSFC06DEC/SB & All parts passed all parametric tests up to a TID of $40 \mathrm{krad}(\mathrm{Si})$ & 2 & $>40$ & $\mathrm{~N}$ \\
\hline LP2951 & $\begin{array}{c}\text { National } \\
\text { Semiconductor }\end{array}$ & 0610A & \begin{tabular}{|l|} 
Micro-Power \\
Adjustable Voltage \\
Regulator
\end{tabular} & $\begin{array}{l}\text { GSFC06NOV/SB } \\
\text { UCD06OCT/SB }\end{array}$ & Passed all parametric tests up to a TID of $40 \mathrm{krad}(\mathrm{Si})$. & 0.02 & 5 to 10 & $\mathrm{~N}$ \\
\hline \multicolumn{9}{|l|}{ Memory } \\
\hline NAND01GW3BZAN6E & ST Microelectronics & 0604 & NAND Flash & $\begin{array}{l}\text { GSFC06MAY/TO; } \\
\text { IUCF06JUL/TO }\end{array}$ & All passed at $30 \mathrm{krad}(\mathrm{Si})$. All failed at $100 \mathrm{krad}(\mathrm{Si})$. & 25 & $30-100$ & $\mathrm{~N}$ \\
\hline AMD29LV256 & Spansion & 0606 & Flash NVM (256M) & GSFC06MAY/TO & $\begin{array}{l}\text { Program/erase modes failed at } 10-20 \mathrm{krad}(\mathrm{Si}) \text {, rad only mode } \\
\text { failed at } 30-50 \mathrm{krad}(\mathrm{Si}) \text {. }\end{array}$ & 25 & $10-20$ & $\mathrm{~N}$ \\
\hline K9F4G08U0A & Samsung & 0624 & NAND Flash & GSFC07JAN/TO & All passed at $100 \mathrm{krad}(\mathrm{Si})$. All failed at $200 \mathrm{krad}(\mathrm{Si})$. & 25 & $100-200$ & $\mathrm{~N}$ \\
\hline TC58FVM7B2ATG-65 & Toshiba & 0539 & NOR Flash (128M) & GSFC06MAY/TO & $\begin{array}{l}\text { Program/erase modes failed }<10 \mathrm{krad}(\mathrm{Si}) \text {, read only mode } \\
\text { failed } 20-40 \mathrm{krad}(\mathrm{Si}) \text {. }\end{array}$ & 25 & 40 & $\mathrm{~N}$ \\
\hline \multicolumn{9}{|l|}{ Programmable Devices } \\
\hline AT22V10 & Atmel & 0437A & EEPLD & GSFC06SEP/CP & $\begin{array}{l}\text { All parts passed } 8 \mathrm{krad}(\mathrm{Si}) \text {. All parts failed functionally at } 15 \\
\mathrm{krad}(\mathrm{Si}) \text {. }\end{array}$ & $\sim 1$ & $>7$ & Y \\
\hline \multicolumn{9}{|c|}{ Voltage References, Regulators \& Comparators } \\
\hline TL431 & Texas Instruments & $\begin{array}{l}\mathrm{n} / \mathrm{a}-\text { test } \\
\text { chips }\end{array}$ & $\begin{array}{l}\text { Prog Shunt } \\
\text { Regulator }\end{array}$ & GSFC06JUL/SB & $\begin{array}{l}\text { All parts passed all functional and parametric electrical tests } \\
\text { up to a total dose of } 20 \mathrm{krad}(\mathrm{Si}) \text {. }\end{array}$ & 0.02 & $>50$ & $\mathrm{~N}$ \\
\hline AD584 & Analog Devices & $0042 \mathrm{~A}$ & Voltage Reference & GSFC06JL/SB & $\begin{array}{l}\text { The AD584 meets all specifications after exposure to TID of } \\
40 \mathrm{krad}(\mathrm{Si}) \text {. }\end{array}$ & 0.02 & $>40$ & $\mathrm{~N}$ \\
\hline AD589 & Analog Devices & 1050 & Voltage Reference & GSFC06JUL/SB & $\begin{array}{l}\text { All devices met specifications for output voltage up to a total } \\
\text { dose of } 50 \mathrm{krad}(\mathrm{Si}) \text {. }\end{array}$ & 0.02 & $>50$ & $\mathrm{~N}$ \\
\hline OMH3075 & $\begin{array}{c}\text { Optek } \\
\text { Technology }\end{array}$ & M0551 & $\begin{array}{l}\text { Optek Hall Effects } \\
\text { Sensor }\end{array}$ & GSFC07JAN/AS & $\begin{array}{l}\text { Meets all specifications for supply current and output } \\
\text { saturation voltage up to a TID of } 40 \mathrm{krad}(\mathrm{Si}) \text {. }\end{array}$ & 0.02 & $>40$ & $\mathrm{~N}$ \\
\hline
\end{tabular}




\begin{tabular}{|c|c|c|c|c|c|c|c|c|}
\hline Part Number & Manufacturer & LDC & Function & \begin{tabular}{|c|} 
Facility Date/P.I \\
(Co-60 source unless \\
otherwise noted).
\end{tabular} & Summary of Results [Test Report] & $\begin{array}{c}\text { Dose rate } \\
(\operatorname{rads}(\mathbf{S i}) / \mathbf{s})\end{array}$ & $\begin{array}{c}\text { Degradation } \\
\text { Level } \\
\text { (krads(Si)) }\end{array}$ & $\begin{array}{l}\text { Appl } \\
\text { Spec }\end{array}$ \\
\hline \multicolumn{9}{|c|}{ Displacement Damage } \\
\hline HCPL-6751 & Agilent Technologies & 0251 & $\begin{array}{l}\text { Power MOSFET } \\
\text { optocoupler }\end{array}$ & IUCF06NOV/JH & $\begin{array}{l}\text { Very little change in dc characteristics, even to } 1 \times 10^{12} \\
\text { protons/cm²; very little change in CTR value, except at lower } \\
\text { drive currents. }\end{array}$ & $\mathrm{n} / \mathrm{a}$ & $\mathrm{n} / \mathrm{a}$ & $\mathrm{N}$ \\
\hline
\end{tabular}




\section{TEST RESULTS AND DISCUSSION}

As in our past workshop compendia of GSFC test results, each DUT has a detailed test report available online at http://radhome.gsfc.nasa.gov [3] describing in further detail, test method, TID conditions/parameters, test results, and graphs of data.

\section{1) National Semiconductor LP2951 Micro-Power Adjustable Voltage Regulator}

The LP2951WG/883 (5962-3870501MXA), micropower adjustable voltage regulator was tested for its sensitivity to TID and DD. The part was manufactured by National Semiconductor and had a lot/date code of 0610A. Because the technology is bipolar, the part was tested for enhanced low dose rate sensitivity (ELDRS) The part was packaged in a 10-lead ceramic surface mount package.

Four parts were irradiated under bias and one part was reserved as a control. During irradiation, all four devices were biased so that their outputs were at $15 \mathrm{~V}$. The devices were exposed to the following total ionizing doses: 0,5 , $10,15,20,30,40 \mathrm{krad}(\mathrm{Si})$. Fig. 1 shows the circuit used to test the device.

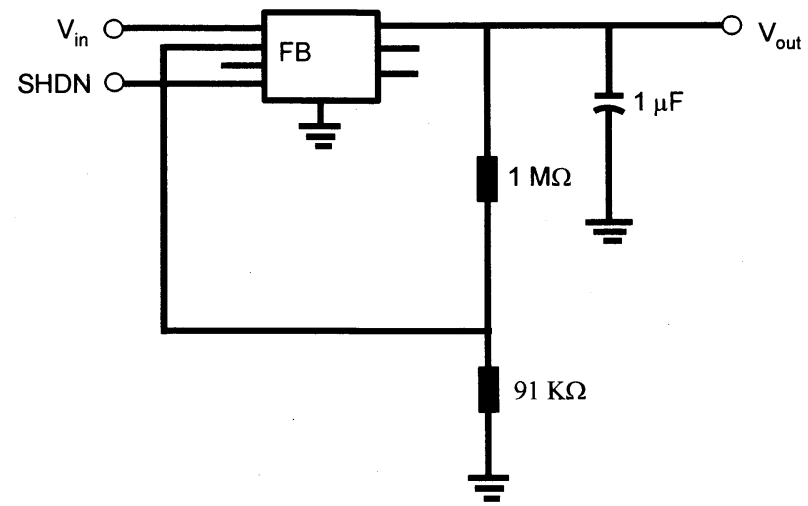

Figure 1. Test setup used for measuring the parametric values.

The devices begin to fail at relatively low doses, as evidenced by the fact that the ground current for one of the devices exceeds the specified value in the data sheet at 5 $\operatorname{krad}(\mathrm{Si})$. By $10 \mathrm{krad}(\mathrm{Si})$, the ground current for the 100 $\mathrm{mA}$ load exceeds the specified value for all four devices. In addition the load regulation on two of the devices was out of specification, as was the dropout voltage. At higher doses, other electrical parameters also failed.

The part was also tested with $63 \mathrm{MeV}$ protons at UCDCNL. Parts were unbiased when exposed to the protons. The proton fluence levels were $1 \times 10^{10}, 3 \times 10^{10}, 6 \times 10^{10}$, $1.6 \times 10^{11}, 3.6 \times 10^{11}$ protons $/ \mathrm{cm}^{2}$. All five parts were irradiated to the first level, then one part was removed and the remaining four were irradiated. This process was repeated until only the final part was exposed to the maximum fluence. In this case as well, the ground current and load regulation went out of specification after the initial fluence of $1 \times 10^{10}$ protons $/ \mathrm{cm}^{2}$.
In summary, this part fails to operate properly at a total ionizing dose of less than $5 \operatorname{krad}(\mathrm{Si})$ and a proton fluence of $1 \times 10^{10}$ protons $/ \mathrm{cm}^{2}$.

\section{2) Analog Devices AD654 voltage-to-frequency converter}

The AD654 is a voltage-to-frequency converter from Analog Devices that was previously total dose tested and found to exceed the full scale error at $18 \mathrm{krad}(\mathrm{Si})$ and the input bias current at $8 \mathrm{krad}(\mathrm{Si})$ [1]. The part was tested at a dose rate of $20 \mathrm{mrad}(\mathrm{Si}) / \mathrm{s}$ (because of time constraints) in the configuration that will be used for flight, which was different from that specified in the data sheet. Very little change was observed in the nonlinearity of the frequency as a function of input voltage or in the input current. Figure 2 shows a small decrease in frequency $(0.6 \%)$ after a dose of $35 \mathrm{krad}(\mathrm{Si})$ for an input of 7 volts, which is well within the requirements for the application.

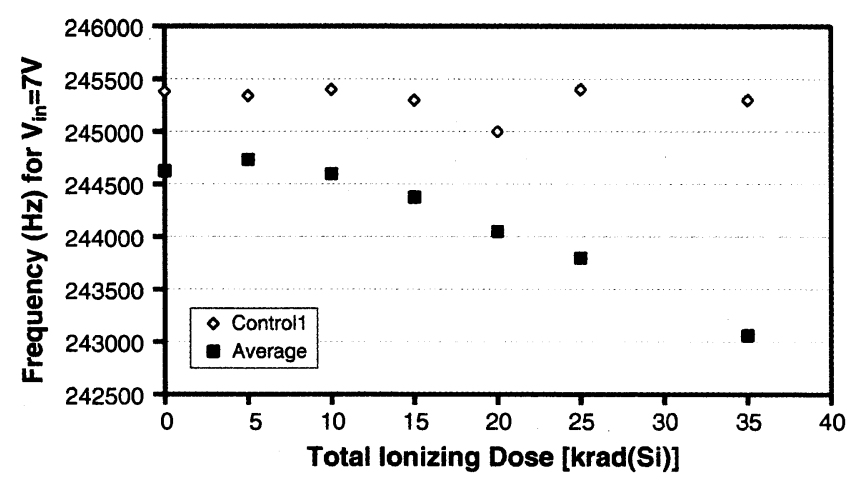

Figure 2. Average output frequency for eight parts as a function of TID and for one control device.

\section{3) Analog Devices AD670 8-bit Analog-to-Digital Converter}

The AD670 is an 8-bit Analog-to-Digital Converter from Analog Devices. The part was tested at a dose rate of 20 $\operatorname{mrad}(\mathrm{Si}) / \mathrm{s}$. One part failed functionally between 5 and 10 $\operatorname{krad}(\mathrm{Si})$. Two parts failed functionally between 10 and 15 $\operatorname{krad}(\mathrm{Si})$ and one part failed functionally between 15 $\mathrm{krad}(\mathrm{Si})$ and $20 \mathrm{krad}(\mathrm{Si})$. The functional failure manifested itself as a complete failure to convert so that the digital output did not change with changes in input voltage.

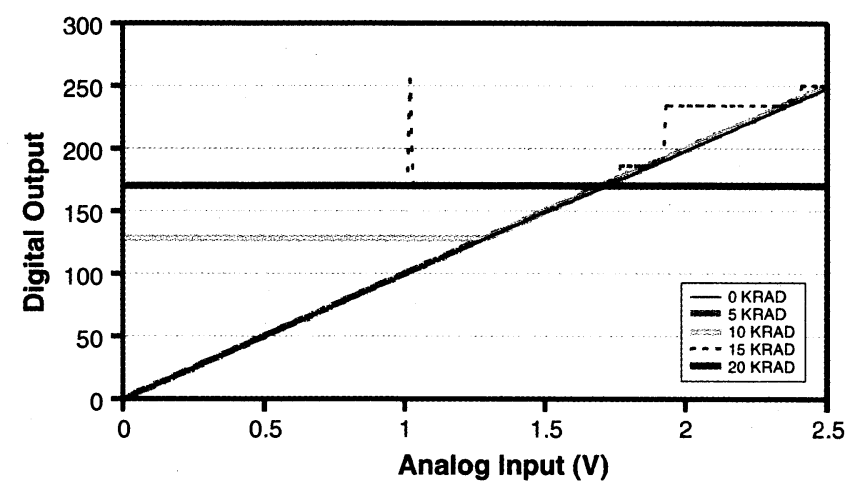

Figure 3. Digital output as a function of analog input for one AD670 at five different TID levels. 


\section{4) Analog Dedices AD589 1.2 Volt Reference}

The AD589 is a 1.2 Volt reference manufactured by Analog Devices. The part was irradiated to $50 \mathrm{krad}(\mathrm{Si})$ at a dose rate of $20 \mathrm{mrad}(\mathrm{Si}) / \mathrm{s}$. The output voltage was measured as a function of input current after each exposure. Figure 4 shows that the output voltage changed with dose but remained within specifications $(1.2 \mathrm{~V}$ to $1.25 \mathrm{~V})$ up to the final dose of $50 \mathrm{krad}(\mathrm{Si})$.

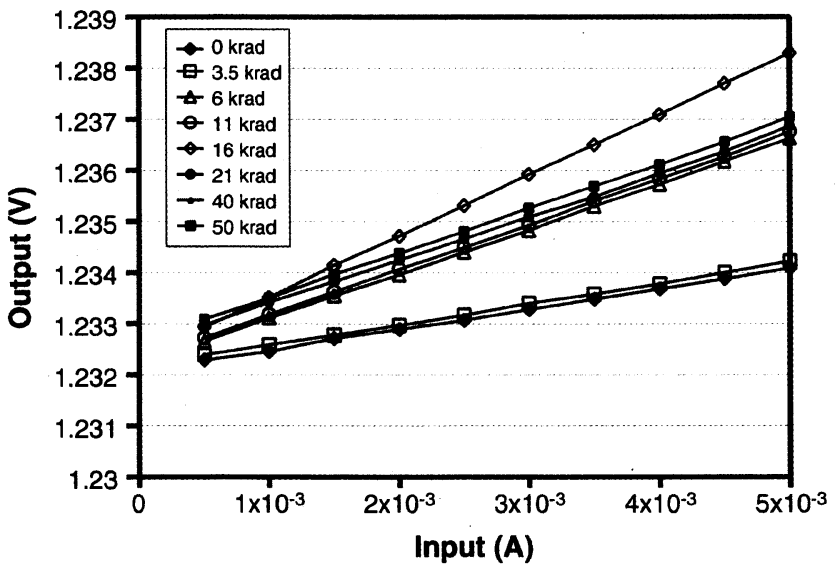

Figure 4. Output Voltage as a function of input current for one AD589 exposed to 8 different total dose levels.

\section{5) Texas Instruments TL431 Three-Terminal Adjustable Voltage Regulator}

The TL431 is a three-terminal adjustable voltage regulator from Texas Instruments. The part was tested to a total dose of $20 \mathrm{krad}(\mathrm{Si})$ at a dose rate of $20 \mathrm{mrad}(\mathrm{Si}) / \mathrm{s}$. All parts passed all parametric tests up to a total dose of 20 $\operatorname{krad}(\mathrm{Si})$. Figure 5 shows the output reference voltage as a function of total dose. Data for both the average of 7 parts and the control device are included. The error bars show the standard deviation for the measurements.

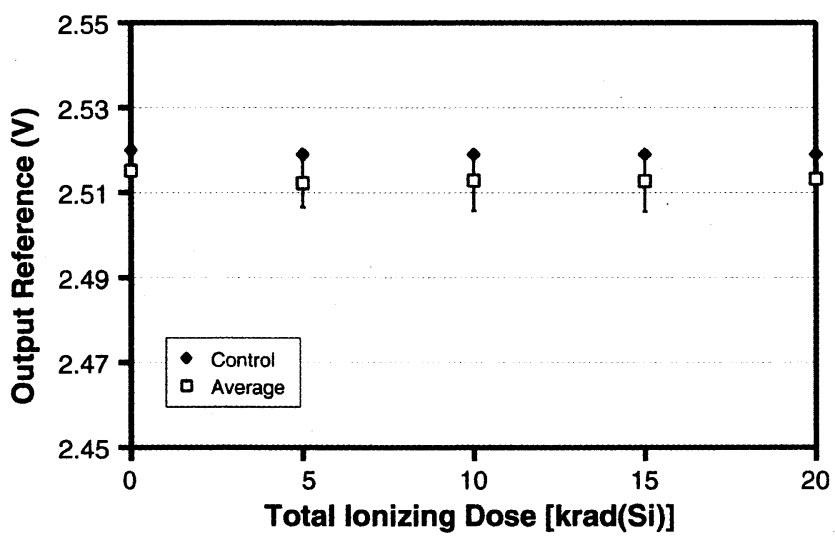

Figure 5. Output reference voltage for the TL431 voltage regulator.

\section{6) K9F4G08U0A NAND Flash Memory - Samsung}

Figure 6 shows the TID response for five NAND flash memories, the STMicroelectronics $1 \mathrm{~Gb}$, Micron $2 \mathrm{~Gb}$ and $4 \mathrm{~Gb}$, Hynix 4Gb, and Samsung 4Gb, and also for two NOR flash memories, Toshiba $128 \mathrm{Mb}$ and Spansion $256 \mathrm{Mb}$. During exposures, the parts were biased, but not actively exercised. Between exposures, the parts were written, read, and erased multiple times, in a total of four patterns, to verify full functionality. The patterns were checkerboard, checkerboard complement, all zeroes, and all ones. The orange bars indicate the highest dose at which all tested parts were still fully functional. For the Micron $4 \mathrm{~Gb}$, one of four samples failed at $100 \mathrm{Krad}$ ( $\mathrm{SiO} 2)$, and all passed at $75 \mathrm{Krad}(\mathrm{SiO} 2)$. For the Samsung $4 \mathrm{~Gb}$, eight of eight parts passed at $100 \mathrm{Krad}(\mathrm{SiO} 2)$, and seven of eight parts passed at $150 \mathrm{Krad}(\mathrm{SiO} 2)$. None of the other parts tested as well as the Samsung $4 \mathrm{~Gb}$. The result is encouraging for many space applications.

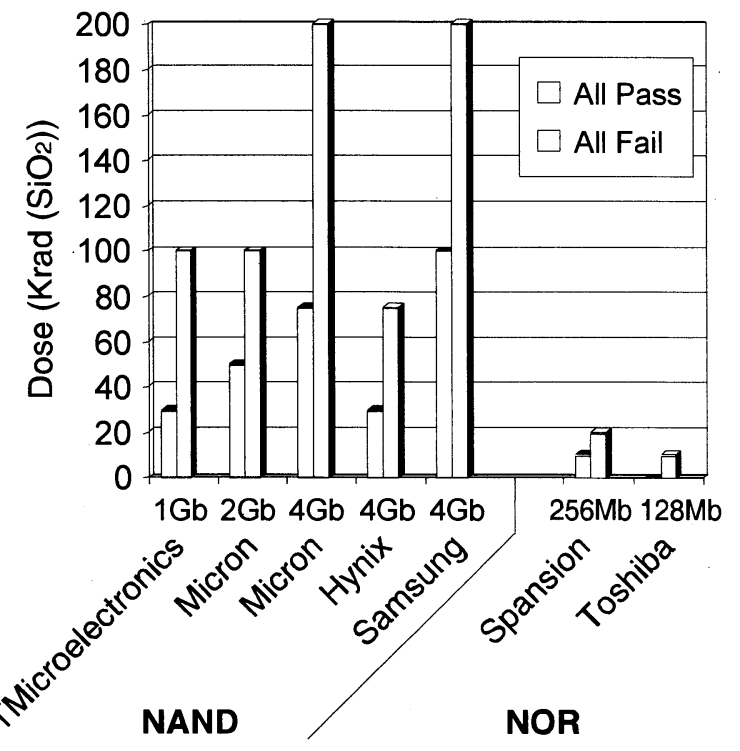

Figure 5. Total dose response of selected NAND and NOR flash memories.

\section{SUMMARY}

We have presented data from recent TID and protoninduced damage tests on a variety of primarily commercial devices. It is the authors' recommendation that this data be used with caution. We also highly recommend lot and application specific testing be performed on any suspect or commercial device.

\section{ACKNOWLEDGMENT}

The authors would like to acknowledge the sponsors of this effort: the NASA Electronic Parts and Packaging (NEPP) program, NASA Flight Projects and the Defense Threat Reduction Agency (DTRA) under IACRO \#0742071. The authors thank members of the Radiation Effects and Analysis Group who contributed to the test results presented here, Craig Stauffer, Hak S. Kim, Anthony M. Dung-Phan, Donald K. Hawkins, Martin A. Carts, James D. Forney, Tim Irwin, Christina M. Seidleck, Stephen R. Cox, and Mark Friendlich. 


\section{REFERENCES}

[1] M. O'Bryan, et al., Compendium of Current Single Event Effects Results for Candidate Spacecraft Electronics for NASA" submitted to the 2007 IEEE NSREC Radiation Effects Data Workshop.

[2] Department of Defense "Test Method sTANDARD Microcircuits," MIL-STD-883 Test Method 1019.7 Ionizing radiation (total dose) test procedure, September 30, 2006, http:/www.dscc.dla.mil/downloads/MIL-STD-883/std883.pdf

[3] NASA/GSFC Radiation Effects and Analysis home page, http://radhome.gsfe.nasa.gov. 